\title{
Diagnosis and management of peripheral artery disease in women
}

\author{
This article was published in the following Dove Press journal: \\ International Journal of Women's Health \\ 13 December 2012 \\ Number of times this article has been viewed
}

\author{
Joy Peacock Walker \\ Jade S Hiramoto \\ Department of Surgery, University \\ of California, San Francisco, California, \\ USA
}

\begin{abstract}
Peripheral artery disease (PAD) is a significant cause of morbidity and mortality in the USA. Not only is it a major cause of functional impairment and limb loss, but it is also strongly associated with an increased risk of myocardial infarction, stroke, and death. Large population studies have demonstrated high rates of PAD in women, but this is not widely recognized by the public or by clinicians. One potential reason for this is that women with PAD are more likely than men to be asymptomatic or have atypical symptoms. In addition, women with PAD experience higher rates of functional decline and may have poorer outcomes after surgical treatment for PAD compared with men. Currently, it is not known if there are sex-specific differences in risk factors for the onset, progression, and surgical outcomes of PAD. This review will focus on the diagnosis and management of PAD in women and examine sex-specific differences in the prevalence, risk factors, presentation, and outcomes of this disease.
\end{abstract}

Keywords: women, peripheral artery diseases, diagnosis, risk factors, management

\section{Introduction}

Peripheral artery disease (PAD) affects approximately 5-10 million people in the $\mathrm{USA}^{1-4}$ and is a significant cause of lower extremity functional impairment, ulceration, and limb loss. Even without these clinical consequences, PAD is an independent predictor of increased cardiovascular $(\mathrm{CV})$ and all-cause mortality. ${ }^{5-16}$ In addition, the economic burden of PAD is higher than one might expect, and comparable to that of coronary artery disease and ischemic stroke. ${ }^{17,18}$

The prevalence and clinical consequences of PAD are similar in magnitude for women and men. Despite this, PAD remains underappreciated in women, and women have been underrepresented in contemporary PAD revascularization studies. ${ }^{19,20}$ As a result, sex-specific differences in the risk factors, management, and outcomes of PAD remain unclear, creating a critical need for clinical research to evaluate sex differences in PAD. In recognition of this growing problem, the American Heart Association recently released a "call to action" to raise awareness of the burden of PAD in women. ${ }^{20}$ This review will seek to highlight sex differences in the risk factors, presentation, diagnosis, and management of PAD.

\section{Prevalence of PAD}

PAD can be symptomatic or asymptomatic, and can be diagnosed based on several different methods: the ankle brachial index (ABI), duplex ultrasound, computed tomography angiography, magnetic resonance angiography, or catheter angiography. Most population-based estimates of $\mathrm{PAD}$ are based on the $\mathrm{ABI}$, the ratio of the 
systolic pressure at the ankle compared with that at the arm; this is an accurate and noninvasive method with which to determine PAD. ${ }^{21-23}$ Traditionally, most studies have used a cut-off point of an ABI of $\leq 0.9$ to define PAD; this was based on the association of this ABI level to anatomic findings on catheter angiography. However, there is substantial research demonstrating elevated $\mathrm{CV}$ risks and mortality in those with an ABI $<1.0 .{ }^{10,15,16,24}$ As a result, in 2011, the American College of Cardiology Foundation/American Heart Association Task Force updated the guidelines for management of patients with PAD and now considers ABI values of $0.9-1.0$ to be abnormal. ${ }^{25}$

Table 1 includes population-based studies where sexspecific PAD prevalence rates could be determined. ${ }^{2,4,26-39}$ Even though male sex has traditionally been reported to be a risk factor for the development of PAD, ${ }^{35,40-42}$ the prevalence of PAD is similar in women and men (and, in some instances, higher in women). Beyond prevalence, there appears to be an increasing population burden of women with PAD. Using US census data from 2010, Hirsch et al calculated a greater number of women than men with PAD among US adults older than 40 years of age. ${ }^{20}$

\section{Risk factors}

Traditional cardiovascular disease (CVD) risk factors (smoking, hypertension, diabetes mellitus, and hyperlipidemia) are strongly associated with the development and progression of PAD in both women and men. . $34,43-45^{-3}$
PAD prevalence increases in both women and men as the population ages, but women tend to be older than men when they present with symptoms of PAD. ${ }^{46-49}$ In addition, African-Americans are disproportionately affected with PAD. 1,2,5,31,33,50,51 Although African-Americans have a higher prevalence of obesity, hypertension, and diabetes mellitus compared with Caucasians, ${ }^{52-55}$ these traditional risk factors alone do not account for the excess risk of PAD in AfricanAmericans. ${ }^{37,50,56}$ The odds for PAD were 1.7 times higher in African-Americans than Caucasians in the Multi-Ethnic Study of Atherosclerosis (MESA) ${ }^{57}$ and 2.4 times higher in African-Americans than in Caucasians in the San Diego Population Study. ${ }^{58}$ These cross-sectional studies demonstrated that the higher odds for PAD in African-Americans than in Caucasians were only modestly attenuated after adjustment for traditional CVD risk factors as well as several inflammatory biomarkers.

It is plausible that women might have different risk factors for PAD development than men. For example, smoking is one of the strongest risk factors for the development of PAD. However, in a cohort of 15,173 African-American and Caucasian individuals aged 45-64 years old, women who had never smoked were still more likely to develop PAD than men $(2.6 \%$ vs $0.4 \%$, respectively.) This remained statistically significant even after adjustment for age, low-density lipoprotein cholesterol, hypertension, and diabetes. ${ }^{31}$ Another study of 1932 participants free of four traditional CVD risk factors (smoking, diabetes, hypertension, and dyslipidemia)

Table I Prevalence of peripheral artery disease (PAD) in men and women in population-based studies

\begin{tabular}{|c|c|c|c|c|c|}
\hline Study & $\mathbf{N}$ & Age (y) & Prevalence in men (\%) & Prevalence in women (\%) & ABI criteria \\
\hline Aboyans et $\mathrm{al}^{26}$ & 1932 & $45-84$ & 4.4 & 12.3 & $<1.0$ \\
\hline \multirow[t]{2}{*}{ Moussa et $\mathrm{al}^{27}$} & 788 & $\geq 70$ or $50-69$ with & 11.6 & 23.3 & $\leq 0.9$ \\
\hline & & DM or tobacco use & & & \\
\hline Ostchega et $\mathrm{al}^{4}$ & 3947 & $\geq 60$ & 12.5 & 12.0 & $<0.9$ \\
\hline Sigvant et $\mathrm{a}^{28}$ & 5080 & $60-90$ & 9.4 & 12.6 & $<0.9$ \\
\hline He et $\mathrm{al}^{29}$ & 2334 & $\geq 60$ & 11.7 & 17.7 & $<0.9$ \\
\hline Kröger et al $\left.\right|^{30}$ & 4735 & $45-75$ & 6.4 & 5.1 & $<0.9$ \\
\hline Zheng et $\mathrm{al}^{31}$ & 15,173 & $45-64$ & 2.5 & 3.6 & $\leq 0.9$ \\
\hline Diehm et $\mathrm{al}^{32}$ & 6880 & $\geq 65$ & 19.8 & 16.8 & $<0.9$ \\
\hline Selvin and Erlinger ${ }^{2}$ & 2174 & $\geq 40$ & 4.5 & 4.2 & $<0.9$ \\
\hline Collins et $\mathrm{al}^{33}$ & 403 & $>50$ & 17.4 & 15.9 & $<0.9$ \\
\hline Murabito et al ${ }^{39}$ & 3313 & $\geq 40$ & 3.9 & 3.3 & $<0.9$ \\
\hline \multirow[t]{2}{*}{ Hirsch et $\mathrm{al}^{34}$} & 6417 & $\geq 70$ or $50-69$ with & 29.7 & 28.5 & $\leq 0.9 *$ \\
\hline & & DM or tobacco use & & & \\
\hline Meijer et $\mathrm{al}^{35}$ & 7715 & $\geq 55$ & 16.9 & 20.5 & $<0.9$ \\
\hline Stoffers et $\mathrm{al}^{36}$ & 3171 & $45-74$ & 7.2 & 6.5 & $<0.95$ \\
\hline Newman et al ${ }^{37}$ & 5084 & $\geq 65$ & 13.8 & 11.4 & $<0.9$ \\
\hline Gofin et $\mathrm{al}^{38}$ & 1592 & $35-64$ & 4.2 & 5.4 & $<0.9$ \\
\hline
\end{tabular}

Note: *Also includes a history of limb revascularization or documentation of PAD in the medical record.

Abbreviations: $\mathrm{ABI}$, ankle brachial index; $\mathrm{DM}$, diabetes mellitus. 
in MESA demonstrated there to be a significant association between female sex and low ABI, suggesting that novel risk factors might contribute more to PAD in women than in men. ${ }^{26}$

It is unknown what these novel risk factors are, as there is a lack of published data in this field of study. However, one possible explanation could be differences in the underlying inflammatory profiles in women and men. Inflammation is a known strong risk factor for PAD. C-reactive protein (CRP) is an acute-phase protein that is elevated in individuals with $\mathrm{PAD}^{59,60}$ and associated with the progression of PAD. ${ }^{61-64}$ In addition, CRP levels may differ according to sex. In both MESA $^{65}$ and the Dallas Heart Study, ${ }^{66}$ women had significantly higher CRP levels than men, despite adjustment for estrogen use, body mass index, and other variables. CRP has been shown in several studies to be an important risk factor for PAD in women. In a prospective cohort study of 27,935 US female health professionals aged over 45 years without baseline vascular disease, CRP was significantly associated with incident symptomatic PAD. ${ }^{67}$ Among 1611 US participants aged 40 years or older without CVD, diabetes, or hypertension, higher CRP levels were positively associated with PAD, despite adjustment for multiple potential confounders. ${ }^{68}$ In this study, women with CRP values in the highest quartile represented the highest risk group.

Another potential novel risk marker for PAD in women is adiponectin. Adiponectin is the most abundant circulating adipokine and has both anti-atherogenic and anti-inflammatory effects. ${ }^{69-71}$ Adiponectin levels are also significantly higher in women than in men, ${ }^{72-76}$ even after adjusting for body mass index. ${ }^{77}$ In a nested case-control study conducted within the Women's Health Study, baseline adiponectin levels were significantly lower in women who subsequently developed PAD. ${ }^{78}$ Further studies are needed to better characterize the possible sex-specific association between adiponectin and PAD.

Chronic kidney disease (CKD) is an independent risk factor for $\mathrm{PAD}^{79,80}$ as well as an independent predictor of mortality in patients with PAD. ${ }^{81,82}$ The prevalence and incidence of PAD is higher among patients with renal insufficiency than among those with normal renal function. ${ }^{79,83-87}$ A cross-sectional analysis demonstrated that persons with renal insufficiency were 2.5-fold more likely to have an ABI of $<0.9$ than those with a normal creatinine clearance, even after adjustment for multiple CVD risk factors. ${ }^{84} \mathrm{~A}$ longitudinal study in the Atherosclerosis Risk in Communities study demonstrated that those with CKD (estimated glomerular filtration rate $<60$ ) had a 1.6 times increased risk for incident PAD over a mean follow-up of 13.1 years. ${ }^{88}$ CKD has become a major public health problem worldwide and, interestingly, there appears to be a higher prevalence of CKD in women than in men. In the National Health and Nutrition Examination Survey, the prevalence of both albuminuria and decreased glomerular filtration rate increased from 1988-1994 to 1999-2004, rising from $8.2 \%$ to $11.1 \%$ in men, and $12.1 \%$ to $15.0 \%$ among women. ${ }^{89}$ In a recent systematic review of population-based studies, the prevalence of CKD was found to be greater in women than in men, regardless of age and ethnicity. ${ }^{90}$ Although CKD is a risk factor for PAD, and CKD prevalence is higher in women than in men, the impact of the association between CKD and PAD according to sex has not yet been thoroughly evaluated.

It was long believed that estrogen was associated with a protective effect against atherosclerotic disease in women. Hence, hormone replacement therapy (HRT) was frequently prescribed to postmenopausal women. The Rotterdam study suggested a protective effect on the risk of PAD in longterm HRT users. ${ }^{91}$ In addition, a recent prospective database of 847,982 postmenopausal women associated the use of HRT with a significant decrease in the prevalence of PAD, despite a high number of atherosclerotic risk factors among the women who used HRT. ${ }^{92}$ However, large randomized controlled trials - the Heart and Estrogen/Progestin Replacement Study (HERS), Women's Health Initiative (WHI) Estrogen plus Progestin Trial, and WHI Estrogen-Alone Study - demonstrated different results. These randomized studies failed to demonstrate a protective effect of HRT on PAD, ${ }^{93-97}$ and the WHI studies demonstrated an increased incidence of early peripheral vascular events in the treatment group. Based on these data, we conclude that HRT does not provide protection against PAD, and may be a risk factor for peripheral arterial events.

\section{Diagnosis of PAD in women}

In both men and women, measurement of ABI is a noninvasive and accurate method with which to assess PAD. An ABI measurement of $\leq 1.0$ is considered abnormal in both men and women. There is some debate over whether "normal" ABI levels are different between men and women, and across ethnic groups. ${ }^{98,99}$ In a fully adjusted model of 1775 healthy participants in MESA, women had approximately 0.02-lower ABI values than men, and African-Americans had about $0.02-$ lower ABI values than Caucasians. ${ }^{99}$ These findings were confirmed in another cohort of middle-aged individuals without PAD. ${ }^{100}$ Although women may have a slightly lower "normal" $\mathrm{ABI}$ value than men, an $\mathrm{ABI}$ of $<1.0$ is still considered 
abnormal in both men and women, and carries considerable risk for adverse $\mathrm{CV}$ events in both sexes. ${ }^{10,15,16}$

Should an anatomic assessment of lower extremity arterial occlusive disease be required for surgical treatment of PAD, computed tomography angiography, magnetic resonance angiography, and catheter angiography are all useful methods with which to delineate the nature and extent of PAD in both women and men. Even though women have smaller lower extremity arteries than do men of the same age, ${ }^{101}$ these imaging modalities appear equally useful in both women and men. However, catheter angiography may be more useful in defining the smaller vessels of the lower extremity, especially in the infrapopliteal and pedal locations and if there is excessive calcification in the arterial wall. ${ }^{102}$

\section{Presentation of PAD}

The hallmark clinical presentation of PAD is that of intermittent claudication, which is described as calf or thigh muscle fatigue or cramping produced by exercise and relieved with rest. However, it is increasingly recognized that $\mathrm{PAD}$ can be present in asymptomatic patients. The "ACC/AHA 2005 Practice Guidelines for the management of patients with peripheral arterial disease" estimates that $<10 \%$ of PAD patients will present with intermittent claudication, another $50 \%$ will have atypical symptoms, and the remaining $40 \%$ will be asymptomatic. ${ }^{40}$ In addition, women are more likely than men to have asymptomatic PAD. ${ }^{29,34,35,103-106}$ In a Swedish population-based study of men and women aged 60-90 years, women were significantly more likely to have an abnormal ABI $(<0.9)$ and be asymptomatic than men $(12.6 \%$ vs $9.4 \%$, respectively, $P=0.03) .{ }^{28}$ Similarly, in a longitudinal study of 2327 patients followed for 7.2 years in The Netherlands, the incidence of asymptomatic PAD was $7.8 \%$ in men and $12.4 \%$ in women. ${ }^{107}$

It is as yet unclear why women with PAD are more likely to be asymptomatic than men. It is possible that women experience walking problems differently, have atypical symptoms, have a lower level of activity, or are just less likely to report symptoms than men. McDermott et al found that leg symptoms and ABI values only correlated in women who walked more than four blocks per week. No association was found between symptoms and abnormal ABI values in less active women. ${ }^{108}$ It is also possible that women with PAD are not really asymptomatic but that the PAD symptoms are masked or misinterpreted as symptoms related to arthritis, osteoporosis, or spinal stenosis. For example, in a crosssectional study of 460 women and men with PAD, women had a higher prevalence of spinal stenosis, which could partially account for sex differences in lower extremity symptoms. ${ }^{109}$ Women with PAD also have poorer lower extremity strength and greater functional impairment than men with PAD. In a longitudinal study of 380 men and women with PAD, women were more likely to become unable to walk for 6 minutes continuously, had greater mobility loss, and faster decline in walking velocity at 4 years of follow-up. ${ }^{46}$

When women do develop lower extremity symptoms and present for PAD treatment, they are more likely to present with advanced disease and critical limb ischemia (CLI). ${ }^{47,106,110}$ Women are more likely to require emergent vascular procedures than $\operatorname{men}^{48,49}$ and are more likely to require amputation as first-line treatment. ${ }^{106}$ It is possible that both underdiagnosis and delayed diagnosis of PAD could contribute to these findings. Atypical presentations of this disease may also play a role in this more advanced presentation among women. Thus, it is critical to recognize PAD early in women. Since women with PAD are more likely to be asymptomatic or present with atypical lower extremity symptoms, practitioners should have a high level of suspicion, consider the diagnosis of PAD in all elderly women, and utilize noninvasive testing such as ABI measurement in addition to clinical history, standardized questionnaires, and physical examination. Utilizing all of these measures will probably result in improved detection of PAD in women. For example, in a study of 2334 participants $\geq 60$ years old, the prevalence of PAD in women was $11.9 \%$ as measured by Rose Questionnaire, $16 \%$ by ABI $<0.9$, and $20.7 \%$ when both methods were employed together. ${ }^{29}$

\section{Treatment of PAD}

Treatment of PAD should begin with risk-factor modification, such as smoking cessation, and appropriate treatment of medical comorbidities, especially hypertension, hyperlipidemia, and diabetes mellitus according to the "Inter-Society Consensus for the Management of Peripheral Arterial Disease" guidelines. ${ }^{111}$ Antiplatelet therapy is an important therapeutic intervention in the secondary prevention of $\mathrm{CV}$ events in those with established atherosclerosis. Aspirin is the most widely used antiplatelet medication and has been extensively investigated in the coronary and carotid circulations. In the initial Antithrombotic Trialists' Collaboration meta-analysis, PAD patients without evidence of vascular disease in other territories did not have a significant reduction in CV events when treated with aspirin. ${ }^{112}$ However, in the more recent meta-analysis of the Antithrombotic Trialists' Collaboration, which included clopidogrel, ticlopidine, dipyridamole, and picotamide in addition to those studies with aspirin, there was 
a $23 \%$ reduction in the risk of vascular events in those with PAD treated with antiplatelet medications. ${ }^{13,114}$ Aspirin use should be considered in those patients with asymptomatic PAD but without clinical evidence of other forms of $\mathrm{CV}$ disease. ${ }^{111}$ Aspirin should be given to those patients with symptomatic PAD or in PAD patients with clinical evidence of coronary or cerebrovascular disease.

These recommendations do not differ based on sex; however, women with PAD are far less likely than men to receive the recommended therapy. In the Reduction of Atherothrombosis for Continued Health (REACH) Registry with 8322 PAD patients, women were significantly less likely than men to be treated with optimal risk-factor control. ${ }^{115}$ Similarly, in a Swedish population-based PAD study, men were more likely to be treated with lipid-lowering therapy, $\beta$-blockers or angiotensin-converting-enzyme-inhibitors, and antiplatelet therapy than women. ${ }^{116}$ In a cohort of men and women undergoing non-cardiac vascular surgery (including 1046 lower limb reconstructions), men were more likely than women to receive disease-specific medications. ${ }^{117}$ Since improvement in risk-factor control is associated with lower 1-year CV event rates, a more aggressive approach for risk-factor modification needs to be employed, especially in women with PAD.

In those patients with symptoms of intermittent claudication, the approach to treatment should include a structured exercise program in addition to the risk-factor modification already described. The potential mechanisms by which exercise increases walking ability in PAD patients include an increase in collateral blood flow past the area of obstruction, improvement in nitric oxide-dependent vasodilation, and a decrease in systemic inflammation. ${ }^{118,119}$ Supervised exercise programs have been shown in multiple prospective studies as well as meta-analyses to significantly increase pain-free walking distance as well as maximal walking time. ${ }^{119-121}$ Selected patients may also benefit from pharmacologic treatment. Although several medications have been used for symptom relief from claudication, the drug with the most substantial evidence for effective treatment of claudication in the USA is cilostazol. Cilostazol (Pletal, Otsuka Pharmaceutical Co, Tokyo, Osaka, and Naruta, Japan) is a phosphodiesterase inhibitor that inhibits platelet aggregation and is an arterial vasodilator. A meta-analysis of 1751 patients in six randomized controlled trials demonstrated a benefit of cilostazol over placebo in peak treadmill performance and quality of life. ${ }^{122}$ At this time, it is not known if there are sexspecific differences in response rates to either a structured exercise program or cilostazol for treatment of intermittent claudication. However, the majority of participants in the studies described were men.

\section{Symptomatic PAD: CLI}

Although PAD affects millions of Americans, only 1\%-2\% of this population will go on to develop CLI, which includes symptoms of lower extremity ischemic pain at rest, foot ulceration, or gangrene. Those who develop CLI are at significantly elevated risk for CV mortality as well as lower extremity amputation. The primary goals of treatment of CLI are to relieve rest pain, heal ulcerations, prevent limb loss, and improve lower extremity function and quality of life. Most patients with CLI will require a lower extremity revascularization procedure in order to meet these goals. Both open surgical bypass procedures and endoluminal angioplasty/stent placement are options for revascularization in women and men.

Even though women with PAD are more likely than men to present for emergent medical attention with CLI, ${ }^{47-49,106,110,123}$ fewer vascular surgical procedures are performed on women. ${ }^{49,124}$ In an analysis of 2.4 million PAD-related inpatient discharge records from New York, New Jersey, and Florida, women were significantly less likely than men to receive a vascular surgical procedure. ${ }^{49}$ In a registry of 5880 infrainguinal arterial reconstructions, only $37 \%$ of the procedures were performed on women, and women were more likely than men to undergo surgery for limb salvage. ${ }^{123}$ The reasons why this is the case, if the prevalence of PAD is the same in women and men, are as yet largely unknown. It is possible that women with PAD are more likely to be asymptomatic for longer periods of time and then only present for treatment when the disease has become advanced. It is also possible that women with PAD are less likely to be offered a surgical intervention because of atypical symptoms.

\section{Outcomes after surgical revascularization}

Sex-specific data on outcomes after lower extremity revascularization procedures are conflicting, with some reports suggesting that women have worse rates of graft patency than men after lower extremity bypass surgery. ${ }^{101,125-127}$ In the largest contemporary series of 9217 patients undergoing lower extremity bypass grafts, female sex was an independent risk factor for early graft failure. ${ }^{128}$ In another series of 1646 patients undergoing lower extremity bypass, female sex was an independent risk factor for graft failure and limb loss. ${ }^{126}$ In a cohort with CLI, women had a sig- 
nificantly higher risk for wound complications, limb loss, and mortality after lower extremity bypass. ${ }^{129}$ In contrast, two large registry studies of infrainguinal arterial reconstruction demonstrated no difference in graft patency and mortality in men and women. ${ }^{123,130}$ In all of these studies, there were fewer women than men, the women were older, and the women presented with disease at a more advanced stage. There have also been several recent studies examining sex differences in outcomes after endovascular treatment of lower extremity PAD, again with mixed results. ${ }^{110,131-133}$ Until women are equally represented in lower extremity revascularization studies, it will be difficult to definitively determine the association between sex and outcomes after lower extremity revascularization.

What has been consistently shown is that female sex is a risk factor for wound complications after lower extremity revascularization procedures. In two separate studies of the National Surgical Quality Improvement Program database, female sex was an independent risk factor for surgical site infection after lower extremity bypass procedures. ${ }^{48,134}$ This is an especially important finding since surgical site infections have been associated with prolonged hospital stay, increased early graft loss, and reoperation. ${ }^{134}$ In a multi-state hospital discharge database, female sex was independently associated with bleeding and infection after lower extremity vascular interventions. ${ }^{47}$

\section{Conclusion}

Although often overlooked, PAD is a common disease in women. Since the elderly is the fastest growing population in the USA, and women have a longer life expectancy than men, there will be an increasing population burden of women with PAD. Clinicians should have a high degree of suspicion for PAD in women, especially in those with other CV risk factors, since women are more likely to be asymptomatic or present with atypical lower extremity symptoms than men. Efforts should be made to ensure that women with $\mathrm{PAD}$ receive appropriate $\mathrm{CV}$ risk-factor modification. Women who undergo surgical revascularization for PAD tend to be older and present with more advanced disease than men, have an increased risk of postoperative wound complications, and may have worse rates of graft patency and limb salvage. This should further emphasize the importance of early detection and treatment of PAD in women.

\section{Disclosure}

The authors report no conflicts of interest in this work.

\section{References}

1. Allison MA, Ho E, Denenberg JO, et al. Ethnic-specific prevalence of peripheral arterial disease in the United States. Am J Prev Med. 2007;32(4):328-333.

2. Selvin E, Erlinger TP. Prevalence of and risk factors for peripheral arterial disease in the United States: results from the National Health and Nutrition Examination Survey, 1999-2000. Circulation. 2004;110(6):738-743.

3. Lloyd-Jones D, Adams R, Carnethon M, et al; American Heart Association Statistics Committee and Stroke Statistics Subcommittee. Heart disease and stroke statistics - 2009 update: a report from the American Heart Association Statistics Committee and Stroke Statistics Subcommittee. Circulation. 2009;119(3):e21-e181.

4. Ostchega Y, Paulose-Ram R, Dillon CF, Gu Q, Hughes JP. Prevalence of peripheral arterial disease and risk factors in persons aged 60 and older: data from the National Health and Nutrition Examination Survey 1999-2004. J Am Geriatr Soc. 2007;55(4):583-589.

5. Weatherley BD, Nelson JJ, Heiss G, et al. The association of the anklebrachial index with incident coronary heart disease: the Atherosclerosis Risk In Communities (ARIC) study, 1987-2001. BMC Cardiovasc Disord. 2007;7:3.

6. Newman AB, Shemanski L, Manolio TA, et al. Ankle-arm index as a predictor of cardiovascular disease and mortality in the Cardiovascular Health Study. The Cardiovascular Health Study Group. Arterioscler Thromb Vasc Biol. 1999;19(3):538-545.

7. Resnick HE, Lindsay RS, McDermott MM, et al. Relationship of high and low ankle brachial index to all-cause and cardiovascular disease mortality: the Strong Heart Study. Circulation. 2004;109(6): 733-739.

8. Leng GC, Fowkes FG, Lee AJ, Dunbar J, Housley E, Ruckley CV. Use of ankle brachial pressure index to predict cardiovascular events and death: a cohort study. BMJ. 7, 1996;313(7070):1440-1444.

9. Hooi JD, Kester AD, Stoffers HE, Rinkens PE, Knottnerus JA, van Ree JW. Asymptomatic peripheral arterial occlusive disease predicted cardiovascular morbidity and mortality in a 7-year follow-up study. J Clin Epidemiol. 2004;57(3):294-300.

10. O’Hare AM, Katz R, Shlipak MG, Cushman M, Newman AB. Mortality and cardiovascular risk across the ankle-arm index spectrum: results from the Cardiovascular Health Study. Circulation. 2006;113(3): 388-393.

11. Abbott RD, Petrovitch H, Rodriguez BL, et al. Ankle/brachial blood pressure in men $>70$ years of age and the risk of coronary heart disease. Am J Cardiol. 2000;86(3):280-284.

12. van der Meer IM, Bots ML, Hofman A, del Sol AI, van der Kuip DA, Witteman JC. Predictive value of noninvasive measures of atherosclerosis for incident myocardial infarction: the Rotterdam Study. Circulation. 2004;109(9):1089-1094.

13. Kornitzer M, Dramaix M, Sobolski J, Degre S, De Backer G. Ankle/ arm pressure index in asymptomatic middle-aged males: an independent predictor of ten-year coronary heart disease mortality. Angiology. 1995;46(3):211-219.

14. Vogt MT, Cauley JA, Newman AB, Kuller LH, Hulley SB. Decreased ankle/arm blood pressure index and mortality in elderly women. JAMA. 1993;270(4):465-469.

15. Criqui $\mathrm{MH}, \mathrm{McCl}$ lland RL, McDermott MM, et al. The anklebrachial index and incident cardiovascular events in the MESA (Multi-Ethnic Study of Atherosclerosis). J Am Coll Cardiol. 2010;56(18):1506-1512.

16. Fowkes FG, Murray GD, Butcher I, et al. Ankle brachial index combined with Framingham Risk Score to predict cardiovascular events and mortality: a meta-analysis. JAMA. 2008;300(2):197-208.

17. Mahoney EM, Wang K, Cohen DJ, et al. One-year costs in patients with a history of or at risk for atherothrombosis in the United States. Circ Cardiovasc Qual Outcomes. 2008;1(1):38-45.

18. Hirsch AT, Hartman L, Town RJ, Virnig BA. National health care costs of peripheral arterial disease in the Medicare population. Vasc Med. 2008;13(3):209-215. 
19. Hoel AW, Kayssi A, Brahmanandam S, Belkin M, Conte MS, Nguyen LL. Under-representation of women and ethnic minorities in vascular surgery randomized controlled trials. J Vasc Surg. 2009;50(2):349-354.

20. Hirsch AT, Allison MA, Gomes AS, et al; American Heart Association Council on Peripheral Vascular Disease; Council on Cardiovascular Nursing; Council on Cardiovascular Radiology and Intervention; Council on Cardiovascular Surgery and Anesthesia; Council on Clinical Cardiology; Council on Epidemiology and Prevention. A call to action: women and peripheral artery disease: a scientific statement from the American Heart Association. Circulation. 2012;125(11): 1449-1472.

21. Greenland P, Abrams J, Aurigemma GP, et al. Prevention Conference V: Beyond secondary prevention: identifying the high-risk patient for primary prevention: noninvasive tests of atherosclerotic burden: Writing Group III. Circulation. 2000;101(1):E16-E22.

22. Osmundson PJ, O’Fallon WM, Clements IP, Kazmier FJ, Zimmerman BR, Palumbo PJ. Reproducibility of noninvasive tests of peripheral occlusive arterial disease. J Vasc Surg. 1985;2(5):678-683.

23. Ouriel K, McDonnell AE, Metz CE, Zarins CK. Critical evaluation of stress testing in the diagnosis of peripheral vascular disease. Surgery. 1982;91(6):686-693.

24. Ono K, Tsuchida A, Kawai H, et al. Ankle-brachial blood pressure index predicts all-cause and cardiovascular mortality in hemodialysis patients. J Am Soc Nephrol. 2003;14(6):1591-1598.

25. 2011 Writing Group Members; 2005 Writing Committee Members; ACCF/AHA Task Force Members. 2011 ACCF/AHA Focused Update of the Guideline for the Management of patients with peripheral artery disease (Updating the 2005 Guideline): a report of the American College of Cardiology Foundation/American Heart Association Task Force on practice guidelines. Circulation. 2011;124(18):2020-2045.

26. Aboyans V, McClelland RL, Allison MA, et al. Lower extremity peripheral artery disease in the absence of traditional risk factors. The Multi-Ethnic Study of Atherosclerosis. Atherosclerosis. 2011; 214(1):169-173.

27. Moussa ID, Jaff MR, Mehran R, et al. Prevalence and prediction of previously unrecognized peripheral arterial disease in patients with coronary artery disease: the Peripheral Arterial Disease in Interventional Patients Study. Catheter Cardiovasc Interv. 2009;73(6): 719-724.

28. Sigvant B, Wiberg-Hedman K, Bergqvist D, et al. A populationbased study of peripheral arterial disease prevalence with special focus on critical limb ischemia and sex differences. J Vasc Surg. 2007;45(6):1185-1191.

29. He Y, Jiang Y, Wang J, Fan L, Li X, Hu FB. Prevalence of peripheral arterial disease and its association with smoking in a population-based study in Beijing, China. J Vasc Surg. 2006;44(2):333-338.

30. Kröger K, Stang A, Kondratieva J, et al; Heinz Nixdorf Recall Study Group. Prevalence of peripheral arterial disease - results of the Heinz Nixdorf recall study. Eur J Epidemiol. 2006;21(4):279-285.

31. Zheng ZJ, Rosamond WD, Chambless LE, et al; ARIC Investigators. Lower extremity arterial disease assessed by ankle-brachial index in a middle-aged population of African Americans and whites: the Atherosclerosis Risk in Communities (ARIC) Study. Am J Prev Med. 2005;29(5 Suppl 1):42-49.

32. Diehm C, Schuster A, Allenberg JR, et al. High prevalence of peripheral arterial disease and co-morbidity in 6880 primary care patients: crosssectional study. Atherosclerosis. 2004;172(1):95-105.

33. Collins TC, Petersen NJ, Suarez-Almazor M, Ashton CM. The prevalence of peripheral arterial disease in a racially diverse population. Arch Intern Med. 2003;163(12):1469-1474.

34. Hirsch AT, Criqui MH, Treat-Jacobson D, et al. Peripheral arterial disease detection, awareness, and treatment in primary care. JAMA. 2001;286(11):1317-1324

35. Meijer WT, Hoes AW, Rutgers D, Bots ML, Hofman A, Grobbee DE Peripheral arterial disease in the elderly: The Rotterdam Study. Arterioscler Thromb Vasc Biol. 1998;18(2):185-192.
36. Stoffers HE, Rinkens PE, Kester AD, Kaiser V, Knottnerus JA. The prevalence of asymptomatic and unrecognized peripheral arterial occlusive disease. Int J Epidemiol. 1996;25(2):282-290.

37. Newman AB, Siscovick DS, Manolio TA, et al. Ankle-arm index as a marker of atherosclerosis in the Cardiovascular Health Study. Cardiovascular Heart Study (CHS) Collaborative Research Group. Circulation. 1993;88(3):837-845.

38. Gofin R, Kark JD, Friedlander Y, et al. Peripheral vascular disease in a middle-aged population sample. The Jerusalem Lipid Research Clinic Prevalence Study. Isr J Med Sci. 1987;23(3):157-167.

39. Murabito JM, Evans JC, Nieto K, Larson MG, Levy D, Wilson PW. Prevalence and clinical correlates of peripheral arterial disease in the Framingham Offspring Study. Am Heart J. 2002;143(6):961-965.

40. Hirsch AT, Haskal ZJ, Hertzer NR, et al; American Association for Vascular Surgery; Society for Vascular Surgery; Society for Cardiovascular Angiography and Interventions; Society for Vascular Medicine and Biology; Society of Interventional Radiology; ACC/AHA Task Force on Practice Guidelines Writing Committee to Develop Guidelines for the Management of Patients With Peripheral Arterial Disease; American Association of Cardiovascular and Pulmonary Rehabilitation; National Heart, Lung, and Blood Institute; Society for Vascular Nursing; TransAtlantic Inter-Society Consensus; Vascular Disease Foundation. ACC/AHA 2005 Practice Guidelines for the management of patients with peripheral arterial disease (lower extremity, renal, mesenteric, and abdominal aortic): a collaborative report from the American Association for Vascular Surgery/Society for Vascular Surgery, Society for Cardiovascular Angiography and Interventions, Society for Vascular Medicine and Biology, Society of Interventional Radiology, and the ACC/AHA Task Force on Practice Guidelines (Writing Committee to Develop Guidelines for the Management of Patients With Peripheral Arterial Disease): endorsed by the American Association of Cardiovascular and Pulmonary Rehabilitation; National Heart, Lung, and Blood Institute; Society for Vascular Nursing; TransAtlantic InterSociety Consensus; and Vascular Disease Foundation. Circulation. 2006;113(11):e463-e654.

41. Kannel WB, Skinner JJ Jr, Schwartz MJ, Shurtleff D. Intermittent claudication. Incidence in the Framingham Study. Circulation. 1970;41(5):875-883.

42. Ness J, Aronow WS, Ahn C. Risk factors for symptomatic peripheral arterial disease in older persons in an academic hospital-based geriatrics practice. J Am Geriatr Soc. 2000;48(3):312-314.

43. Murabito JM, D’Agostino RB, Silbershatz H, Wilson WF. Intermittent claudication. A risk profile from The Framingham Heart Study. Circulation. 1997;96(1):44-49.

44. Al-Delaimy WK, Merchant AT, Rimm EB, Willett WC, Stampfer MJ, $\mathrm{Hu}$ FB. Effect of type 2 diabetes and its duration on the risk of peripheral arterial disease among men. Am J Med. 2004;116(4):236-240.

45. Sentí M, Nogués X, Pedro-Botet J, Rubiés-Prat J, Vidal-Barraquer F. Lipoprotein profile in men with peripheral vascular disease. Role of intermediate density lipoproteins and apoprotein E phenotypes. Circulation. 1992;85(1):30-36.

46. McDermott MM, Ferrucci L, Liu K, et al. Women with peripheral arterial disease experience faster functional decline than men with peripheral arterial disease. J Am Coll Cardiol. 2011;57(6):707-714.

47. Vouyouka AG, Egorova NN, Salloum A, et al. Lessons learned from the analysis of gender effect on risk factors and procedural outcomes of lower extremity arterial disease. J Vasc Surg. 2010;52(5):1196-1202.

48. Jain AK, Velazquez-Ramirez G, Goodney PP, Edwards MS, Corriere MA. Gender-based analysis of perioperative outcomes associated with lower extremity bypass. Am Surg. 2011;77(7):844-849.

49. Egorova N, Vouyouka AG, Quin J, et al. Analysis of gender-related differences in lower extremity peripheral arterial disease. J Vasc Surg. 2010;51(2):372-378. e1; discussion 378-379.

50. Kullo IJ, Bailey KR, Kardia SL, Mosley TH Jr, Boerwinkle E, Turner ST. Ethnic differences in peripheral arterial disease in the NHLBI Genetic Epidemiology Network of Arteriopathy (GENOA) study. Vasc Med. 2003;8(4):237-242. 
51. Criqui MH, Vargas V, Denenberg JO, et al. Ethnicity and peripheral arterial disease: the San Diego Population Study. Circulation. 2005;112(17):2703-2707.

52. Centers for Disease Control and Prevention. Differences in prevalence of obesity among black, white, and Hispanic adults - United States, 2006-2008. MMWR Morb Mortal Wkly Rep. 2009;58(27):740-744.

53. Cowie CC, Harris MI, Silverman RE, Johnson EW, Rust KF. Effect of multiple risk factors on differences between blacks and whites in the prevalence of non-insulin-dependent diabetes mellitus in the United States. Am J Epidemiol. 1993;137(7):719-732.

54. Minor DS, Wofford MR, Jones DW. Racial and ethnic differences in hypertension. Curr Atheroscler Rep. 2008;10(2):121-127.

55. Hertz RP, Unger AN, Cornell JA, Saunders E. Racial disparities in hypertension prevalence, awareness, and management. Arch Intern Med. 2005;165(18):2098-2104.

56. Kuller L, Fisher L, McClelland R, et al. Differences in prevalence of and risk factors for subclinical vascular disease among black and white participants in the Cardiovascular Health Study. Arterioscler Thromb Vasc Biol. 1998;18(2):283-293.

57. Allison MA, Criqui MH, McClelland RL, et al. The effect of novel cardiovascular risk factors on the ethnic-specific odds for peripheral arterial disease in the Multi-Ethnic Study of Atherosclerosis (MESA). J Am Coll Cardiol. 2006;48(6):1190-1197.

58. Ix JH, Allison MA, Denenberg JO, Cushman M, Criqui MH. Novel cardiovascular risk factors do not completely explain the higher prevalence of peripheral arterial disease among African Americans. The San Diego Population Study. J Am Coll Cardiol. 2008;51(24):2347-2354.

59. Beckman JA, Preis O, Ridker PM, Gerhard-Herman M. Comparison of usefulness of inflammatory markers in patients with versus without peripheral arterial disease in predicting adverse cardiovascular outcomes (myocardial infarction, stroke, and death). Am J Cardiol. 2005;96(10):1374-1378.

60. McDermott MM, Guralnik JM, Corsi A, et al. Patterns of inflammation associated with peripheral arterial disease: the InCHIANTI study. Am Heart J. 2005;150(2):276-281.

61. Ridker PM, Cushman M, Stampfer MJ, Tracy RP, Hennekens CH. Plasma concentration of C-reactive protein and risk of developing peripheral vascular disease. Circulation. 1998;97(5):425-428.

62. Ridker PM, Stampfer MJ, Rifai N. Novel risk factors for systemic atherosclerosis: a comparison of C-reactive protein, fibrinogen, homocysteine, lipoprotein(a), and standard cholesterol screening as predictors of peripheral arterial disease. JAMA. 2001;285(19):2481-2485.

63. Tzoulaki I, Murray GD, Lee AJ, Rumley A, Lowe GD, Fowkes FG. C-reactive protein, interleukin-6, and soluble adhesion molecules as predictors of progressive peripheral atherosclerosis in the general population: Edinburgh Artery Study. Circulation. 2005;112(7):976-983

64. McDermott MM, Guralnik JM, Greenland P, et al. Inflammatory and thrombotic blood markers and walking-related disability in men and women with and without peripheral arterial disease. JAm Geriatr Soc. 2004;52(11):1888-1894.

65. Lakoski SG, Cushman M, Criqui M, et al. Gender and C-reactive protein: data from the Multiethnic Study of Atherosclerosis (MESA) cohort. Am Heart J. 2006;152(3):593-598.

66. Khera A, McGuire DK, Murphy SA, et al. Race and gender differences in C-reactive protein levels. $J$ Am Coll Cardiol. 2005;46(3):464-469.

67. Pradhan AD, Shrivastava S, Cook NR, Rifai N, Creager MA, Ridker PM. Symptomatic peripheral arterial disease in women: nontraditional biomarkers of elevated risk. Circulation. 2008;117(6):823-831.

68. Shankar A, Li J, Nieto FJ, Klein BE, Klein R. Association between C-reactive protein level and peripheral arterial disease among US adults without cardiovascular disease, diabetes, or hypertension. Am Heart J. 2007;154(3):495-501.

69. Matsuzawa Y. Adiponectin: Identification, physiology and clinical relevance in metabolic and vascular disease. Atheroscler Suppl. 2005;6(2):7-14

70. Shimada K, Miyazaki T, Daida H. Adiponectin and atherosclerotic disease. Clin Chim Acta. 2004;344(1-2):1-12.
71. Giannessi D, Maltinti M, Del Ry S. Adiponectin circulating levels: a new emerging biomarker of cardiovascular risk. Pharmacol Res. 2007:56(6):459-467.

72. Cnop M, Havel PJ, Utzschneider KM, et al. Relationship of adiponectin to body fat distribution, insulin sensitivity and plasma lipoproteins: evidence for independent roles of age and sex. Diabetologia. 2003;46(4):459-469.

73. Boyne MS, Bennett NR, Cooper RS, et al. Sex-differences in adiponectin levels and body fat distribution: longitudinal observations in Afro-Jamaicans. Diabetes Res Clin Pract. 2010;90(2):e33-e36.

74. Saltevo J, Kautiainen H, Vanhala M. Gender differences in adiponectin and low-grade inflammation among individuals with normal glucose tolerance, prediabetes, and type 2 diabetes. Gend Med. 2009;6(3):463-470.

75. Silha JV, Krsek M, Skrha JV, Sucharda P, Nyomba BL, Murphy LJ. Plasma resistin, adiponectin and leptin levels in lean and obese subjects: correlations with insulin resistance. Eur J Endocrinol. 2003;149(4):331-335.

76. Arita Y, Kihara S, Ouchi N, et al. Paradoxical decrease of an adiposespecific protein, adiponectin, in obesity. Biochem Biophys Res Commun. 1999;257(1):79-83.

77. Salas-Salvadó J, Granada M, Bulló M, Corominas A, Casas P, Foz M. Plasma adiponectin distribution in a Mediterranean population and its association with cardiovascular risk factors and metabolic syndrome. Metabolism. 2007;56(11):1486-1492.

78. Ho DY, Cook NR, Britton KA, et al. High-molecular-weight and total adiponectin levels and incident symptomatic peripheral artery disease in women: a prospective investigation. Circulation. 2011;124(21):2303-2311.

79. Selvin E, Kottgen A, Coresh J. Kidney function estimated from serum creatinine and cystatin $\mathrm{C}$ and peripheral arterial disease in NHANES 1999-2002. Eur Heart J. 2009;30(15):1918-1925.

80. O'Hare AM, Newman AB, Katz R, et al. Cystatin C and incident peripheral arterial disease events in the elderly: results from the Cardiovascular Health Study. Arch Intern Med. 2005;165(22):2666-2670.

81. O'Hare AM, Bertenthal D, Shlipak MG, Sen S, Chren MM. Impact of renal insufficiency on mortality in advanced lower extremity peripheral arterial disease. JAm Soc Nephrol. 2005;16(2):514-519.

82. Pasqualini L, Schillaci G, Pirro M, et al. Renal dysfunction predicts long-term mortality in patients with lower extremity arterial disease. J Intern Med. 2007;262(6):668-677.

83. Leskinen Y, Salenius JP, Lehtimäki T, Huhtala H, Saha H. The prevalence of peripheral arterial disease and medial arterial calcification in patients with chronic renal failure: requirements for diagnostics. $\mathrm{Am} J$ Kidney Dis. 2002;40(3):472-479.

84. O'Hare AM, Glidden DV, Fox CS, Hsu CY. High prevalence of peripheral arterial disease in persons with renal insufficiency: results from the National Health and Nutrition Examination Survey 1999-2000. Circulation. 2004;109(3):320-323.

85. O'Hare AM, Vittinghoff E, Hsia J, Shlipak MG. Renal insufficiency and the risk of lower extremity peripheral arterial disease: results from the Heart and Estrogen/Progestin Replacement Study (HERS). J Am Soc Nephrol. 2004;15(4):1046-1051.

86. de Vinuesa SG, Ortega M, Martinez P, Goicoechea M, Campdera FG, Luño J. Subclinical peripheral arterial disease in patients with chronic kidney disease: prevalence and related risk factors. Kidney Int Suppl. 2005;93:S44-S47.

87. Mostaza JM, Suarez C, Manzano L, et al; MERITO Study Group. Relationship between ankle-brachial index and chronic kidney disease in hypertensive patients with no known cardiovascular disease. $J$ Am Soc Nephrol. 2006;17(12 Suppl 3):S201-S205.

88. Wattanakit K, Folsom AR, Selvin E, Coresh J, Hirsch AT, Weatherley BD. Kidney function and risk of peripheral arterial disease: results from the Atherosclerosis Risk in Communities (ARIC) Study. J Am Soc Nephrol. 2007;18(2):629-636.

89. Coresh J, Selvin E, Stevens LA, et al. Prevalence of chronic kidney disease in the United States. JAMA. 2007;298(17):2038-2047. 
90. Zhang QL, Rothenbacher D. Prevalence of chronic kidney disease in population-based studies: systematic review. BMC Public Health. 2008;8:117.

91. Westendorp IC, in't Veld BA, Grobbee DE, et al. Hormone replacement therapy and peripheral arterial disease: the Rotterdam study. Arch Intern Med. 2000;160(16):2498-2502.

92. Rockman CB, Maldonado TS, Jacobowitz GR, Adelman MA, Riles TS. Hormone replacement therapy is associated with a decreased prevalence of peripheral arterial disease in postmenopausal women Ann Vasc Surg. 2012;26(3):411-418.

93. Hulley S, Grady D, Bush T, et al. Randomized trial of estrogen plus progestin for secondary prevention of coronary heart disease in postmenopausal women. Heart and Estrogen/progestin Replacement Study (HERS) Research Group. JAMA. 1998;280(7):605-613.

94. Rossouw JE, Anderson GL, Prentice RL, et al; Writing Group for the Women's Health Initiative Investigators. Risks and benefits of estrogen plus progestin in healthy postmenopausal women: principal results From the Women's Health Initiative randomized controlled trial. JAMA. 2002;288(3):321-333.

95. Grady D, Herrington D, Bittner V, et al; HERS Research Group. Cardiovascular disease outcomes during 6.8 years of hormone therapy: Heart and Estrogen/progestin Replacement Study follow-up (HERS II). JAMA. 2002;288(1):49-57.

96. Hsia J, Simon JA, Lin F, et al. Peripheral arterial disease in randomized trial of estrogen with progestin in women with coronary heart disease the Heart and Estrogen/Progestin Replacement Study. Circulation. 2000;102(18):2228-2232.

97. Hsia J, Criqui MH, Herrington DM, et al. Conjugated equine estrogens and peripheral arterial disease risk: the Women's Health Initiative. $\mathrm{Am}$ Heart J. 2006;152(1):170-176.

98. London GM, Guerin AP, Pannier B, Marchais SJ, Stimpel M. Influence of sex on arterial hemodynamics and blood pressure. Role of body height. Hypertension. 1995;26(3):514-519.

99. Aboyans V, Criqui MH, McClelland RL, et al. Intrinsic contribution of gender and ethnicity to normal ankle-brachial index values: the Multi-Ethnic Study of Atherosclerosis (MESA). J Vasc Surg. 2007;45(2):319-327.

100. Singh S, Bailey KR, Kullo IJ. Ethnic differences in ankle brachial index are present in middle-aged individuals without peripheral arterial disease. Int $J$ Cardiol. 2011. Epub June 6.

101. AhChong AK, Chiu KM, Wong M, Yip AW. The influence of gender difference on the outcomes of infrainguinal bypass for critical limb ischaemia in Chinese patients. Eur J Vasc Endovasc Surg. 2002;23(2):134-139.

102. Lawrence JA, Kim D, Kent KC, Stehling MK, Rosen MP, Raptopoulos V. Lower extremity spiral CT angiography versus catheter angiography Radiology. 1995;194(3):903-908.

103. Vogt MT, Cauley JA, Kuller LH, Hulley SB. Prevalence and correlates of lower extremity arterial disease in elderly women. Am J Epidemiol. 1993;137(5):559-568.

104. Brevetti G, Bucur R, Balbarini A, et al. Women and peripheral arterial disease: same disease, different issues. $J$ Cardiovasc Med (Hagerstown). 2008;9(4):382-388.

105. McDermott MM, Fried L, Simonsick E, Ling S, Guralnik JM. Asymptomatic peripheral arterial disease is independently associated with impaired lower extremity functioning: the women's health and aging study. Circulation. 2000;101(9):1007-1012.

106. Vouyouka AG, Kent KC. Arterial vascular disease in women. J Vasc Surg. 2007;46(6):1295-1302.

107. Hooi JD, Kester AD, Stoffers HE, Overdijk MM, van Ree JW, Knottnerus JA. Incidence of and risk factors for asymptomatic peripheral arterial occlusive disease: a longitudinal study. $\mathrm{Am} \mathrm{J}$ Epidemiol. 2001;153(7):666-672.

108. McDermott MM, Guralnik JM, Ferrucci L, et al. Asymptomatic peripheral arterial disease is associated with more adverse lower extremity characteristics than intermittent claudication. Circulation. 2008;117(19):2484-2491.
109. McDermott MM, Greenland P, Liu K, et al. Sex differences in peripheral arterial disease: leg symptoms and physical functioning. $J \mathrm{Am}$ Geriatr Soc. 2003;51(2):222-228.

110. Gallagher KA, Meltzer AJ, Ravin RA, et al. Gender differences in outcomes of endovascular treatment of infrainguinal peripheral artery disease. Vasc Endovascular Surg. 2011;45(8):703-711.

111. Norgren L, Hiatt WR, Dormandy JA, Nehler MR, Harris KA, Fowkes FG; TASC II Working Group. Inter-Society Consensus for the Management of Peripheral Arterial Disease (TASC II). J Vasc Surg. 2007;45 Suppl S:S5-S67.

112. Collaborative overview of randomised trials of antiplatelet therapy $-\mathrm{I}$ : Prevention of death, myocardial infarction, and stroke by prolonged antiplatelet therapy in various categories of patients. Antiplatelet Trialists' Collaboration. BMJ. 1994;308(6921):81-106.

113. Antithrombotic Trialists' Collaboration. Collaborative meta-analysis of randomised trials of antiplatelet therapy for prevention of death, myocardial infarction, and stroke in high risk patients. $B M J$. 2002;324(7329):71-86.

114. Clagett GP, Sobel M, Jackson MR, Lip GY, Tangelder M, Verhaeghe R. Antithrombotic therapy in peripheral arterial occlusive disease: the Seventh ACCP Conference on Antithrombotic and Thrombolytic Therapy. Chest. 2004;126(Suppl 3):609S-626S.

115. Cacoub PP, Abola MT, Baumgartner I, et al; REACH Registry Investigators. Cardiovascular risk factor control and outcomes in peripheral artery disease patients in the Reduction of Atherothrombosis for Continued Health (REACH) Registry. Atherosclerosis. 2009;204(2):e86-e92.

116. Sigvant B, Wiberg-Hedman K, Bergqvist D, Rolandsson O, Wahlberg E. Risk factor profiles and use of cardiovascular drug prevention in women and men with peripheral arterial disease. European J Cardiovasc Prev Rehabil. 2009;16(1):39-46.

117. Grootenboer N, Hunink MG, Hoeks S, Hendriks JM, van Sambeek MR, Poldermans D. The impact of gender on prognosis after non-cardiac vascular surgery. Eur J Vasc Endovasc Surg. 2011;42(4): $510-516$.

118. Hamburg NM, Balady GJ. Exercise rehabilitation in peripheral artery disease: functional impact and mechanisms of benefits. Circulation. 2011;123(1):87-97.

119. Stewart KJ, Hiatt WR, Regensteiner JG, Hirsch AT. Exercise training for claudication. N Engl J Med. 2002;347(24):1941-1951.

120. Gardner AW, Poehlman ET. Exercise rehabilitation programs for the treatment of claudication pain. A meta-analysis. JAMA. 1995;274(12):975-980.

121. Watson L, Ellis B, Leng GC. Exercise for intermittent claudication. Cochrane Database Syst Rev. 2008;4:CD000990.

122. Regensteiner JG, Ware JE Jr, McCarthy WJ, et al. Effect of cilostazol on treadmill walking, community-based walking ability, and healthrelated quality of life in patients with intermittent claudication due to peripheral arterial disease: meta-analysis of six randomized controlled trials. J Am Geriatr Soc. 2002;50(12):1939-1946.

123. Roddy SP, Darling RC 3rd, Maharaj D, et al. Gender-related differences in outcome: an analysis of 5880 infrainguinal arterial reconstructions. J Vasc Surg. 2003;37(2):399-402.

124. Norman PE, Semmens JB, Lawrence-Brown M, Holman CD. The influence of gender on outcome following peripheral vascular surgery: a review. Cardiovasc Surg. 2000;8(2):111-115.

125. Enzler MA, Ruoss M, Seifert B, Berger M. The influence of gender on the outcome of arterial procedures in the lower extremity. Eur $J$ Vasc Endovasc Surg. 1996;11(4):446-452.

126. Robinson WP 3rd, Owens CD, Nguyen LL, Chong TT, Conte MS, Belkin M. Inferior outcomes of autogenous infrainguinal bypass in Hispanics: an analysis of ethnicity, graft function, and limb salvage. J Vasc Surg. 2009;49(6):1416-1425.

127. Magnant JG, Cronenwett JL, Walsh DB, Schneider JR, Besso SR, Zwolak RM. Surgical treatment of infrainguinal arterial occlusive disease in women. J Vasc Surg. 1993;17(1):67-76; discussion 76-78. 
128. Lancaster RT, Conrad MF, Patel VI, Cambria RP, LaMuraglia GM. Predictors of early graft failure after infrainguinal bypass surgery: a risk-adjusted analysis from the NSQIP. Eur J Vasc Endovasc Surg. 2012;43(5):549-555.

129. Nguyen LL, Brahmanandam S, Bandyk DF, et al. Female gender and oral anticoagulants are associated with wound complications in lower extremity vein bypass: an analysis of 1404 operations for critical limb ischemia. J Vasc Surg. 2007;46(6):1191-1197.

130. Harris EJ Jr, Taylor LM Jr, Moneta GL, Porter JM. Outcome of infrainguinal arterial reconstruction in women. J Vasc Surg. 1993;18(4):627-634; discussion 634-636.

131. Timaran CH, Stevens SL, Freeman MB, Goldman MH. External iliac and common iliac artery angioplasty and stenting in men and women. J Vasc Surg. 2001;34(3):440-446.
132. Pulli R, Dorigo W, Pratesi G, Fargion A, Angiletta D, Pratesi C. Gender-related outcomes in the endovascular treatment of infrainguinal arterial obstructive disease. J Vasc Surg. 2012;55(1): 105-112.

133. DeRubertis BG, Vouyouka A, Rhee SJ, et al. Percutaneous intervention for infrainguinal occlusive disease in women: equivalent outcomes despite increased severity of disease compared with men. JVasc Surg. 2008;48(1):150-157; discussion 157-158.

134. Greenblatt DY, Rajamanickam V, Mell MW. Predictors of surgical site infection after open lower extremity revascularization. J Vasc Surg. 2011;54(2):433-439.

\section{Publish your work in this journal}

The International Journal of Women's Health is an international, peerreviewed open-access journal publishing original research, reports, editorials, reviews and commentaries on all aspects of women's healthcare including gynecology, obstetrics, and breast cancer. The manuscript management system is completely online and includes a very quick and fair peer-review system, which is all easy to use. Visit http://www.dovepress.com/testimonials.php to read real quotes from published authors.

Submit your manuscript here: http://www.dovepress.com/international-journal-of-womens-health-journal 